\title{
HOSPITAL-ACQUIRED PNEUMONIA IN NEWBORNS WITH BIRTH WEIGHT LESS THAN 1500 GRAMS: RISK FACTORS AND CAUSES
}

\author{
Nevena Folic ${ }^{1,2}$, Zorana Djordjevic ${ }^{3}$, Marko Folic ${ }^{2,4}$, Slavica Markovic ${ }^{1,2}$, Biljana Vuletic ${ }^{1,2}$, Dragana Savic ${ }^{1,2}$, Olgica Gajovic ${ }^{2,5}$, Slobodan Jankovic ${ }^{2,4}$ \\ ${ }^{1}$ Pediatric Clinic, Clinical Centre Kragujevac, Kragujevac, Serbia \\ ${ }^{2}$ Faculty of Medical Sciences, University of Kragujevac, Kragujevac, Serbia \\ ${ }^{3}$ Department of Hospital Infections Control, Clinical Centre Kragujevac, Kragujevac, Serbia \\ ${ }^{4}$ Clinical Pharmacology Department, Clinical Centre Kragujevac, Kragujevac, Serbia \\ ${ }^{5}$ Infectious Diseases Clinic, Clinical Centre Kragujevac, Kragujevac, Serbia

\section{BOLNIČKE PNEUMONIJE KOD NOVOROĐENČADI ROĐENIH SA TELE- SNOM MASOM MANJOM OD 1500 GRAMA: \\ FAKTORI RIZIKA I UZROČNICI}

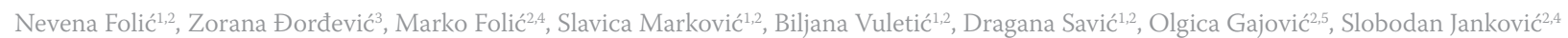 \\ ${ }^{1}$ Klinika za pedijatriju, Klinički centar Kragujevac, Kragujevac, Srbija \\ ${ }^{2}$ Fakultet medicinskih nauka, Univerzitet u Kragujevcu, Kragujevac, Srbija \\ ${ }^{3}$ Odsek za kontrolu bolničkih infekcija, Klinički centar Kragujevac, Kragujevac, Srbija \\ ${ }^{4}$ Služba za kliničku farmakologiju, Klinički centar Kragujevac, Kragujevac, Srbija \\ ${ }^{5}$ Klinika za infektivna bolesti, Klinički centar Kragujevac, Kragujevac, Srbija
}

Received / Primljen: 29.03.2016.

Accepted / Prihvaćen: 26.04.2016.

\begin{abstract}
Low birth weight newborns ( $\leq 1500$ grams) are at a high risk of acquiring hospital infections due to the immaturity of the immune system, lack of efficient structural barriers, and an incomplete development of endogenous microbial flora.

The aim of this study was to reveal the potential risk factors for hospital-acquired pneumonia in low birth weight newborns.

This study was a prospective cohort design with a nested case-control study and was conducted between January $1^{\text {st }}, 2012$ and June 30 $0^{\text {th }}, 2015$ at the Neonatology Department, Clinical Centre Kragujevac, Serbia. There were 1140 newborns hospitalized at the Neonatology Department for longer than 48 hours during the study period, and 169 of them (14.82\%) weighed less than 1500 grams at birth. In total, 73 (43.19\%) newborns with low birth weights developed HIs. The most prevalent HI was hospital pneumonia ( $n=64,87.67 \%)$.
\end{abstract}

Although univariate analyses identified many risk factors with a significant influence on the occurrence of hospital pneumonia, multivariate analysis identified only the following two independent risk factors for hospital pneumonia in newborns with birth weights below 1500 grams: mechanical ventilation ( $p=0.003, O R=68.893,95 \%$ $C I=4.285-1107.699)$ and longer hospitalization $(p=0.003$, $O R=1.052$, 95\% CI=1.017-1.088). Almost all of the pathogens isolated from the patients with pneumonia were gram-negative bacteria (98.50\%). More than half of all of the isolates were Acinetobacter spp (37.50\%) and Enterobacter spp (18.75\%).

Our study showed that mechanical ventilation and prolonged hospitalization were significant risk factors for the development of hospital pneumonia in newborns with birth weights below 1500 grams.

Keywords: Newborns; low birth weight; nosocomial infections; pneumonia

\section{SAŽETAK}

Novorođenčad sa malom telesnom masom na rođenju ( $\leq 1500$ grama) odlikuju se prisustvom visokog rizika za razvoj bolničkih infekcija usled nezrelosti imunog sistema, nedostatka funkcionalno razvijenih strukturalnih barijera kao $i$ nepotpuno razvijene endogene mikrobne flore.

Utvrditi potencijalne faktore rizika za razvoj bolničkih pneumonija kod novorođenčadi rođenih sa malom telesnom masom.

Sprovedenaje prospektivna kohortna studija sa ugnježdenom studijom tipa slučaj-kontrola u periodu od 1. januara 2012. godine do 30. juna 2015. godine u Centru za neonatologiju Kliničkog centra Kragujevac, Republika Srbija. Ukupno je u pomenutom periodu praćenja bilo 1140 novorođenčadi hospitalizovanih u Centru za neonatologiju duže od 48 časova, od kojih je njih 169 (14,82\%) imalo telesnu masu na rodenju manju od 1500 grama. Intrahospitalnu infekciju iz pomenute grupe od interesa razvilo je $73(43,19 \%)$ novorođenčadi sa malom telesnom masom na rođenju, i to najčešce pneumoniju ( $n=64 ; 87,67 \%)$.

Mada je univarijantna analiza ukazala na značajan uticajbrojnih faktora rizika na razvoj intrahospitalnih upala pluća, multivarijantnom analizom su, pak, identifikovana samo dva nezavisna faktora rizika za razvoj bolničkih pneumonija kod novorođenčadi sa telesnom masom ispod 1500 grama na rođenju: mehanička ventilacija ( $p=0,003, O R=68,893,95 \%$ $C I=4,285-1107,699)$ i produžena hospitalizacija $(p=0,003$, $O R=1,052,95 \% C I=1,017-1,088)$. Većina patogenih uzročnika infekcija izolovanih kod pacijenata sa upalom pluća bili su iz grupe Gram negativnih bakterija (98,5\%). Više od polovine svih izolata pripadali su vrstama Acinetobacter (37,50\%) odnosno Enterobacter (18,75\%) bakterija.

Naše istraživanje je pokazalo da mehanička ventilacija $i$ produžena hospitalizacija predstavljaju značajne faktore rizika za razvoj bolničke pneumonije kod novorođenčadi sa telesnom masom na rođenju manjom od 1500 grama.

Ključne reči. Neonatus; mala telesna masa na rođenju; bolničke infekcije, pneumonija 


\section{INTRODUCTION}

Hospital infections (HIs) are the main cause of morbidity and mortality in neonatal intensive care units (NICUs) and are accompanied by major utilization of resources, prolonged hospitalization and increased costs $(1,2)$. More than $30 \%$ of hospitalized newborns develop HIs, sometimes followed by a lasting impairment of health, which places HIs on the short list of the most serious public health problems (3-5).

Premature newborns and low birth weight newborns ( $\leq$ 1500 grams) have the highest risk of acquiring HIs due to the immaturity of their immune systems, lack of efficient structural barriers, and an incomplete development of endogenous microbial flora (6-8). They are also exposed to numerous invasive diagnostic and therapeutic procedures, which often open the doors for the entrance of pathogens (placement of venous and urinary catheters, endotracheal intubation, mechanical ventilation, and total parenteral nutrition). Although the most frequent type of $\mathrm{HI}$ is intrahospital pneumonia, there are only a few published studies regarding the epidemiology of HIs.

The aim of this study was to reveal the potential risk factors for hospital-acquired pneumonia in low birth weight newborns (b.w. $\leq 1500 \mathrm{~g}$ ) and establish a basis for planning preventive measures.

\section{MATERIALS AND METHODS}

Our study was a prospective cohort design with a nested case-control study and was conducted between January $1^{\text {st }}$, 2012 and June $30^{\text {th }}, 2015$ at the Neonatology Department, Clinical Centre Kragujevac, Serbia. This department has 30 beds (15 devoted to intensive care and 15 to special care), occupying 6 rooms in total. The personnel wash their hands with a $0.75 \%$ solution of povidone iodine, and rapid disinfection is performed with various alcohols. In total, eight physicians take care of the patients, and there is one nurse per three intensive care beds, and one nurse per four special care beds. The following measures for prevention of HIs are routinely conducted in this department: hand hygiene, installation of alcohol-based hydrogels for hand disinfection in the ward, performing environmental cultures, assessing staffing, and grouping infected or colonized patients.

The study was approved by Ethics Committee of the Clinical Centre Kragujevac.

The inclusion criteria were a birth weight below 1500 grams and hospitalization longer than 48 hours. Newborns with hospital-acquired pneumonia were classified as cases, and newborns without pneumonia were classified as control. Other types of hospital infections were among the exclusion criteria for this study.

The diagnosis of HI and the determination of the exact anatomical location were established according to the standard diagnostic criteria of the Center for Prevention and Control of Diseases (CDC) in Atlanta (9), which considers all neonatal infections, whether acquired during de- livery or hospitalization, as hospital-acquired unless evidence indicated transplacental acquisition.

All newborns admitted to this department were submitted to the following diagnostic tests: peripheral blood leukocyte count, platelet count, C-reactive protein, and swabs and blood cultures if required. On the third day of hospitalization, the newborns were routinely examined for signs of pneumonia with laboratory tests; clinical signs, such as fever; respiratory problems (apnea, tachypnea, bradycardia, wheezing, rhonchi, cough, increased production of respiratory secretions, and new onset of purulent sputum or change in character of sputum); chest X-ray when requested by paediatricians; and microbial cultures.

Relevant study data were taken from the patients' files (patient's history, patient's charts, reports from laboratories, etc.), by examination of the patients and from the paediatricians in charge of the patients. Each case was analysed separately by a representative of the Department of Prevention and Hospital Infections Control of the Clinical Centre at Kragujevac, and complex cases were elaborated by the group of investigators. The patients were followed until they were cured, discharged from the hospital or died.

The data on the potential risk factors were collected by means of special epidemiological questionnaires, which included the following:

1. Details about the mother and the pregnancy: maternal age at the moment of delivery, maternal diseases, and whether it was singleton or twin pregnancy;

2. Details about the delivery: date, type (vaginal or by Caesarean section), whether there was rupture of the membranes or placental detachment, macroscopic inspection of the amniotic fluid (milky, meconium stained or green) and term of delivery; and

3. Details about the newborn: sex, gestational age (determined by the ultrasound examination), birth weight (grams), Apgar score values in the $1^{\text {st }}$ and $5^{\text {th }}$ minute after birth, reasons for admission to the hospital, diagnostic and therapeutic procedures that were undertaken (venous catheters, mechanical ventilation) and the results of the laboratory tests upon admission.

Isolation and identification of bacterial pathogens were performed in the Department for Microbiology at the Clinical Centre Kragujevac by means of conventional biochemical methods (10).

Collected data were analysed using the Statistical Package for Social Science for Windows (SPSS), version 18. At first, descriptive statistics were calculated, including measures of central tendency (mean and median), measures of variability (standard deviation), and relative numbers. After checking for normality of the data distribution with the KolmogorovSmirnov test, the differences between the groups in continuous variables were tested by Student's t-test, and the differences in frequencies were tested by Chi-square test. The differences were considered significant if the probability of the null hypothesis was less than 0.05 . A multivariate logistic regression model was constructed to assess the simultaneous 
influence of the independent variables in the development of hospital pneumonia and their mutual interaction.

\section{RESULTS}

There were 1140 newborns hospitalized at the Neonatology Department for longer than 48 hours during the study period, and 169 of them (14.82\%) weighed less than 1500 grams at birth. In total, 73 (43.19\%) newborns developed HIs. The most prevalent HI was hospital pneumonia ( $n=64$, $87.67 \%$ ), and only 9 newborns had some other type of HI (6 cases of urinary tract infection, 2 cases of sepsis and 1 case of omphalitis), and they were excluded from further study.

The median gestational age of newborns weighing less than 1500 grams was 29.58 weeks (range, 23 -38 weeks), and the median birth weight was 1195 grams (range, 500-1500 grams). The reasons for admission to the Neonatology Department were premature birth (96.25\%), respiratory distress syndrome (70.0\%), asphyxiation (66.25\%), infection at birth $(8.0 \%)$, necrotizing enterocolitis (7.5\%) and congenital anomalies (3.1\%).

The results of the univariate analysis of risk factors for hospital pneumonia in newborns with birth weights below

Table 1. Risk factors for hospital pneumonia in newborns with birth weights below 1500 grams (univariate logistic regression analysis)

\begin{tabular}{|c|c|c|c|c|}
\hline \multirow{2}{*}{ Variable } & \multicolumn{2}{|c|}{ Neonates } & \multirow{2}{*}{$x^{2} / t$} & \multirow{2}{*}{$p$ value } \\
\hline & Cases $(n=64)$ & Controls $(n=96)$ & & \\
\hline Maternal age (years) & $29.66 \pm 6.53$ & $30.29 \pm 6.24$ & $\mathrm{t}=0.619$ & 0.537 \\
\hline Rupture of membranes & $15(23.4)$ & $17(17.7)$ & $X^{2}=0.788$ & 0.375 \\
\hline$\leq 24$ hours & $12(18.8)$ & $6(6.3)$ & $X^{2}=6.009$ & $0.014^{*}$ \\
\hline Caesarean section & $30(46.9)$ & $47(48.9)$ & $X^{2}=0.067$ & 0.796 \\
\hline Placental detachment & $8(12.5)$ & $3(3.1)$ & $X^{2}=5.272$ & $0.022^{*}$ \\
\hline Changed appearance of amniotic fluid & $16(25.0)$ & $15(15.6)$ & $X^{2}=2.161$ & 0.142 \\
\hline Maternal disease in pregnancy & $17(26.6)$ & $17(17.7)$ & $X^{2}=1.799$ & 0.180 \\
\hline Vaginitis and urine tract infection in mother & $9(14.1)$ & $4(4.2)$ & $X^{2}=5.038$ & $0.025^{*}$ \\
\hline Male gender & $31(48.4)$ & $43(44.8)$ & $X^{2}=0.205$ & 0.650 \\
\hline Gestational age (weeks) & $28.77 \pm 2.42$ & $29.92 \pm 3.43$ & $\mathrm{t}=2.325$ & $0.021^{*}$ \\
\hline$\leq 27$ & $20(31.3)$ & $22(22.9)$ & $X^{2}=1.377$ & 0.241 \\
\hline $28-31$ & $39(60.9)$ & $41(42.7)$ & $X^{2}=5.107$ & $0.024^{*}$ \\
\hline $32-36$ & $5(7.8)$ & $30(31.3)$ & $X^{2}=12.343$ & $<0.001 \%$ \\
\hline $37-41$ & $1(1.6)$ & $2(2.1)$ & $X^{2}=0.037$ & 0.812 \\
\hline Birth weight (grams) & $1175.78 \pm 230.05$ & $1196.30 \pm 284.43$ & $\mathrm{t}=0.482$ & 0.637 \\
\hline$\leq 1000$ grams & $17(26.6)$ & $24(25.0)$ & $X^{2}=0.049$ & 0.824 \\
\hline Apgar score in the first minute & $4.44 \pm 2.25$ & $5.53 \pm 2.33$ & $\mathrm{t}=2.137$ & $0.034^{*}$ \\
\hline$\leq 3$ & $26(40.6)$ & $24(25.0)$ & $X^{2}=4.364$ & $0.037^{*}$ \\
\hline $4-6$ & $24(37.5)$ & $37(38.5)$ & $X^{2}=0.018$ & 0.894 \\
\hline $7-10$ & $14(21.9)$ & $35(36.5)$ & $X^{2}=3.844$ & 0.050 \\
\hline Apgar score in the fifth minute & $4.95 \pm 1.91$ & $5.92 \pm 2.06$ & $\mathrm{t}=2.982$ & $0.003^{*}$ \\
\hline$\leq 3$ & $18(28.1)$ & $13(13.5)$ & $X^{2}=5.228$ & $0.022^{*}$ \\
\hline $4-6$ & $30(46.9)$ & $35(36.5)$ & $X^{2}=1.727$ & 0.189 \\
\hline $7-10$ & $17(26.6)$ & $46(47.9)$ & $x^{2}=7.335$ & $0.007^{*}$ \\
\hline Twin pregnancy & $13(20.3)$ & $26(27.1)$ & $X^{2}=0.955$ & 0.328 \\
\hline Delivery before term & $64(100.0)$ & $90(93.8)$ & $X^{2}=4.156$ & $0.041^{*}$ \\
\hline Respiratory distress syndrome & $52(81.3)$ & $55(57.3)$ & $X^{2}=9.950$ & $0.002^{*}$ \\
\hline Asphyxia & $44(68.8)$ & $59(61.5)$ & $X^{2}=0.890$ & 0.345 \\
\hline Stay of peripheral venous catheter (days) & $34.72 \pm 16.35$ & $12.07 \pm 7.80$ & $\mathrm{t}=-11.731$ & $<0.001 \%$ \\
\hline Mechanical ventilation & $63(98.4)$ & $44(45.8)$ & $X^{2}=47.968$ & $<0.001 *$ \\
\hline Duration of mechanical ventilation (days) & $20.86 \pm 14.17$ & $7.16 \pm 5.76$ & $t=-6.069$ & $<0.001 *$ \\
\hline White cells count $\left(x 10^{9} / \mathrm{L}\right)$ & $18.71 \pm 12.55$ & $18.26 \pm 14.00$ & $\mathrm{t}=-0.211$ & 0.833 \\
\hline C-reactive protein $(\mathrm{mg} / \mathrm{L})$ & $5.23 \pm 9.97$ & $5.89 \pm 11.36$ & $\mathrm{t}=0.397$ & 0.705 \\
\hline Durationof hospitalization (days) & $73.22 \pm 27.74$ & $27.48 \pm 21.62$ & $t=-1.690$ & $<0.001^{*}$ \\
\hline
\end{tabular}

NOTE: Results are presented as $\bar{x} \pm \mathrm{SD}$, if not otherwise indicated;

* significant difference

** Diseases include: anemia, gestational diabetes mellitus, hypertension, vaginitis and urine tract infection 
Table 2. Multivariate analysis (logistic regression) of risk factors for hospital pneumonia in newborns with birth weight below 1500 grams

\begin{tabular}{|c|c|c|c|}
\hline Risk factors & B & OR & 95\% CI \\
\hline Mechanical ventilation & 4.233 & 68.893 & $4.285-1107.699$ \\
\hline Duration of hospitalization (days) & 0.051 & 1.052 & $1.017-1.088$ \\
\hline
\end{tabular}

NOTE: Only significant factors are presented

$\mathrm{B}$ - coefficient of logistic regression analysis; OR - Odds Ratio; CI - confidence interval

1500 grams are shown in Table 1 . The following risk factors for hospital pneumonia reached the level of statistical significance: rupture of the membranes $\leq 24$ hours before delivery $(p=0.014)$, placental detachment $(p=0.022)$, maternal urinary tract infection or vaginitis $(p=0.025)$, lower gestational age $(\mathrm{p}=0.021)$, lower Apgar score in the first $(p=0.034)$ and the fifth minute $(p=0.003)$ after birth, premature birth $(\mathrm{p}=0.041)$, respiratory distress syndrome $(\mathrm{p}=0.002)$, longer stay with peripheral venous catheter $(\mathrm{p}<0.001)$, mechanical ventilation $(\mathrm{p}<0.001)$, longer duration of mechanical ventilation $(\mathrm{p}<0.001)$ and longer hospitalization $(\mathrm{p}<0.001)$.

Multivariate analysis identified only the following two independent risk factors for hospital pneumonia in newborns with birth weights below 1500 grams: mechanical ventilation $(\mathrm{p}=0.003, \mathrm{OR}=68.893,95 \% \mathrm{CI}=4.285-1107.699)$ and longer hospitalization $(\mathrm{p}=0.003, \mathrm{OR}=1.052,95 \%$ CI=1.017-1.088) (Table 2).

Almost all of the pathogens isolated from the patients with pneumonia belonged to gram-negative bacteria (98.44\%). More than half of all of the isolates were Acinetobacter spp (37.50\%) and Enterobacter spp (18.75\%). A detailed distribution of isolated pathogens is shown in Table 3.

\section{DISCUSSION}

Our study included a large number of potential risk factors for hospital pneumonia in newborns with birth weights below 1500 grams. However, although the univariate analysis identified many significant risk factors, the multivariate analysis showed that there were only two independent risk factors for hospital pneumonia as follows: mechanical ventilation and longer hospitalization.

Table 3. Distribution of isolates from respiratory tract in newborns with birth weight less than 1500 grams, who developed hospital pneumonia

\begin{tabular}{|c|c|}
\hline Pathogens & $\mathbf{n}(\mathbf{\%})$ \\
\hline Acinetobacter spp & $23(37.50)$ \\
\hline Enterobacter spp & $12(18.75)$ \\
\hline Klebsiella spp & $10(15.63)$ \\
\hline Escherichia coli & $8(12.50)$ \\
\hline Stenotrophomonas maltophilia & $6(9.38)$ \\
\hline Pseudomonas aeruginosa & $4(6.25)$ \\
\hline Coagulase negative staphylococcus & $1(1.56)$ \\
\hline Total & $64(100.0)$ \\
\hline
\end{tabular}

It was not surprising that mechanical ventilation was a risk factor for hospital pneumonia in our patients because the same was shown in other studies (11-13). Yalaz and associates (14) had found that the highest incidence of hospital pneumonia was observed in infants with birth weights $\leq 1000$ grams who were on mechanical ventilation. This intervention is often necessary for infants with respiratory failure, poor gas exchange, increased effort for breathing, apnea of prematurity, and/or the need for surfactant-replacement therapy. However, invasive respiratory support is associated with lung injury and adverse neurologic outcomes, and it sometimes allows entry of infectious agents that cause pneumonia. It was recommended that exposure to mechanical ventilation should be limited $(15,16)$. Some authors suggest that significant reduction in the frequency of pneumonia could be achieved by non-invasive ventilation instead, such as nasal continuous positive pressure ventilation or nasal synchronized intermittent mandatory ventilation (14).

Patients on mechanical ventilation need frequent and intensive contact with medical staff, which may disrupt protective barriers. Additionally, these patient are frequently submitted to more invasive diagnostic and therapeutic procedures (venous catheterization, urinary bladder catheterization, etc.), which create additional opportunities for the entrance of bacterial pathogens (17). Patients in countries with limited health resources are especially vulnerable because understaffing and work overload lead to errors and omissions in aseptic techniques and introduction of bacteria into blood or the respiratory or urinary tract.

Our study also linked the occurrence of hospital pneumonia with prolonged hospitalization $(\mathrm{OR}=1.052$, 95\% CI = 1.017-1.088), which was expected because previous studies had demonstrated associations of this factor with other types of HIs (18-20). The patients in the hospital frequently become colonized with multiresistant strains of bacteria, and when the delicate balance of the normal bodily microbial flora is disrupted by indiscriminate use of antimicrobial agents and normal body defences are impaired by the underlying disease, they become easy prey for such strains. The hospital environment, especially that of intensive care units, is home of many multiresistant bacterial strains. It was noted that in newborns who were hospitalized for prolonged periods, the normal microbial flora was replaced by multiresistant bacterial strains from the hospital environment (21). Additionally, prolonged hospitalization increases chances for transfer of multiresistant bacteria from newborns with infection to those without. 
It is interesting that none of the factors that were related to the mother, the pregnancy or the newborns themselves had a significant influence on the emergence of hospital pneumonia in this group of patients. Such results support the theory that hospital pneumonia in newborns with birth weights below 1500 grams is primarily a "deviceassociated, health care-associated infection". To decrease the frequency of hospital pneumonia in this group of newborns, utilization of mechanical ventilation should be limited to when absolutely necessary.

The distribution of bacterial pathogens in our study was similar to the distributions described in other studies from developing countries, and gram-negative bacteria were the most frequent causative agents of hospital pneumonia (11, $22,23)$. It is important to emphasize that infections with these pathogens are associated with high mortality rates. In our study, more than half of the isolated strains were Acinetobacter spp (37.50\%) and Enterobacter spp (18.75\%). The geographical variation in the prevalence of certain gramnegative microorganisms may be caused by the frequency of mechanical ventilation, inappropriate sampling of respiratory tract secretions, and biofilm formation. However, in developed countries in Europe and North America, the predominant cause of pneumonia in the NICUs are gram-positive cocci, which are now more often resistant to many antibiotics than previously described (e.g., methicillin-resistant S. aureus (MRSA)) (24-26). Because every unit has its own unique endemic flora, active surveillance for HIs is critical to guiding empiric antibiotic therapy and implementing effective preventive strategies.

It was proven that simple and low-cost measures can reduce the incidence of HIs $(22,27)$. The lessons learned from Western European countries (28) support our efforts in organization and regular training of the infection control team at our hospital. Although infection control teams at hospitals have only recently become obligatory in Serbia, we had established an infection control team at our hospital (with qualified epidemiologist and infection control nurses) five years ago. This team is responsible for the daily surveillance of all newborns, early detection of symptoms and signs of an infection in close collaboration with responsible clinicians and organization of infection control and prevention measures. Additional study is needed to estimate the effectiveness of these measures in our hospital.

Our study had certain limitations. First, the study was conducted in a single hospital; therefore, the results could be influenced by the choice of patients and the peculiarities of local medical practices. Second, we could not reliably estimate the occurrence of the transfer of pathogens between the patients.

In conclusion, our study showed that mechanical ventilation and prolonged hospitalization were significant risk factors for the development of hospital pneumonia in newborns with birth weights below 1500 grams. Low birth weight newborns with these risk factors should receive more stringent care with administration of special preventive measures to avoid development of hospital pneumonia.

\section{Acknowledgements}

This study was partially financed by research grant No. 175007 given by the Serbian Ministry of Education, Science and Technological Development and by research grant JP 14/11 given by the Faculty of Medical Sciences, University of Kragujevac.

The authors have no conflict of interests concerning the article's content or conclusions.

\section{REFERENCES}

1. Klevens RM, Edwards JR, Richards CL, Horan TC, Gaynes RP, Pollock DA, et al. Estimating Health CareAssociated Infections and Deaths in U.S. Hospitals, 2002. Public Health Reports 2007; 122: 160-6.

2. Dachy A, Battisti O. How to explore...nosocomial infections in neonatology. Rev Med Liege. 2014; 69 (7-8): 454-9.

3. Auriti C, Ronchetti MP, Pezzotti P, Marrocco G, Quondamcarlo A, Seganti G, et al. Determinants of nosocomial infection in 6 neonatal intensive care units: an Italian multicenter prospective cohort study. Infect Control Hosp Epidemiol. 2010; 31(9): 926-33.

4. Ghoneim M, Khashaba M, El-Gilany AH, Abdel-Hady D. Nosocomial infection surveillance in an Egyptian neonatal intensive care unit. J Hosp Infect. 2013; 83(3): 196-9.

5. Babazono A, Kitajima H, Nishimaki S, Nakamura T, Shiga S, Hayakawa M, et al. Risk factors for nosocomial infection in the neonatal intensive care unit by the Japanese Nosocomial Infection Surveillance (JANIS). Acta Med Okayama. 2008; 62(4): 261-8.

6. Bartels DB, Schwab F, Geffers C, Poets CF, Gastmeie P. Nosocomial infection in small for gestational age newborns with birth weight <1500 g: a multicentre analysis. Arch Dis Child Fetal Neonatal Ed. 2007; 92(6): F449-F453.

7. Olsen AL, Reinholdt J, Jensen AM, Andersen LP, Jensen ET. Nosocomial infection in a Danish neonatal intensive care unit: a prospective study. Acta Paediatr. 2009; 98: 1294-8.

8. Djordjevic ZM, Markovic-Denic L, Folic MM, Igrutinovic Z, Jankovic SM. Health care-acquired infections in neonatal intensive care units: risk factors and etiology. Am J Infect Control. 2015; 43(1): 86-8.

9. Garner JS, Jarvis WR, Emori TG, Horan TC, Hughes JM. CDC definitions for nosocomial infections. Am J Infect Control. 1988; 16: 128-40.

10. Clinical and Laboratory Standards Institute. Performance standards for antimicrobial susceptibility testing; 21st informational supplement. CLSI M100S21 Clinical and Laboratory Standards Institute. Wayne, PA; 2011.

11. Tekin R, Dal T, Pirinccioglu H, Oygucu SE. A 4-year surveillance of device-associated nosocomial infections in a neonatal intensive care unit. Pediatr Neonatol. 2013; 54(5): 303-8. 
12. Mahfouz AA, Al-Azraqi TA, Abbag FI, Al-Gamal MN, Seef S, Bello CS. Nosocomial infections in a neonatal intensive care unit in south-western Saudi Arabia. East Mediterr Health J. 2010; 16(1): 40-4.

13. Orsi GB, d'Ettorre G, Panero A, Chiarini F, Vullo V, Venditti M. Hospital-acquired infection surveillance in a neonatal intensive care unit. Am J Infect Control. 2009; 37(3): 201-3.

14. Yalaz M, Altun-Köroğlu O, Ulusoy B, Yıldız B, Akisu M, Vardar F, et al. Evaluation of device-associated infections in a neonatal intensive care unit. Turk J Pediatr. 2012; 54 (2): 128-35.

15. Gizzi C, Moretti C, Agostino R. Weaning from mechanical ventilation. J Matern Fetal Neonatal Med. 2011; 24 Suppl 1: 61-3.

16. Brown MK, Di Blasi RM. Mechanical ventilation of the premature neonate. Respir Care. 2011; 56(9): 1298-311.

17. Távora AC, Castro AB, Militão MA, Girão JE, Ribeiro KB, Távora LG. Risk factors for nosocomial infection in a Brazilian neonatal intensive care unit. Braz J Infect Dis. 2008; 12(1): 75-9.

18. Abdel-Wahab F, Ghoneim M, Khashaba M, El-Gilany AH, Abdel-Hady D. Nosocomial infection surveillance in an Egyptian neonatal intensive care unit. J Hosp Infect. 2013; 83(3): 196-9.

19. Mireya UA, Martí PO, Xavier KV, Cristina LO, Miguel MM, Magda CM. Nosocomial infections in paediatric and neonatal intensive care units. J Infect. 2007; 54 (3): 212-20.

20. Couto RC, Carvalho EA, Pedrosa TM, Pedroso ER, Neto MC, Biscione FM. A 10-year prospective surveillance of nosocomial infections in neonatal intensive care units. Am J Infect Control. 2007; 35(3): 183-9.
21. Srivastava S, Shetty N. Healthcare-associated infections in neonatal units: lessons from contrasting worlds. J Hosp Infect. 2007; 65(4): 292-306.

22. Zaidi AK, Huskins WC, Thaver D, Bhutta ZA, Abbas Z, Goldmann DA. Hospital-acquired neonatal infections in developing countries. Lancet. 2005; 365(9465): 1175-88.

23. Azab SFA, Sherbiny HS, Saleh SH, Elsaeed WF, Elshafiey MM, Siam AG, et al. Reducing ventilator-associated pneumonia in neonatal intensive care unit using "VAP prevention Bundle": a cohort study. BMC Infectious Diseases. 2015;

24. Geffers C, Baerwolff S, Schwab F, Gastmeier P. Incidence of healthcare-associated infections in high-risk neonates: results from the German surveillance system for very-low-birthweight infants. J Hosp Infect. 2008; 68(3): 214-21.

25. Aelami MH, Lotfi M, Zingg W. Ventilator-associated pneumonia in neonates, infants and children. Antimicrobial Resistance and Infection Control. 2014; 3: 30.

26. Srinivasan R, Asselin J, Gildengorin G, Wiener-Kronish J, Flori HR. A prospective study of ventilator-associated pneumonia in children. Pediatrics. 2009; 123(4):1108-15.

27. Landre-Peigne C, Ka AS, Peigne V, Bougere J, Seye MN, Imbert P. Efficacy of an infection control programme in reducing nosocomial bloodstream infections in a Senegalese neonatal unit. J Hosp Infect 2011; 79(2): 161-5.

28. Bion J, Richardson A, Hibbert P, Beer J, Abrusci T, McCutcheon M, et al. Matching Michigan Collaboration \& Writing Committee. 'Matching Michigan': a 2-year stepped interventional programme to minimise central venous catheter-blood stream infections in intensive care units in England. BMJ Qual Saf. 2013; 22(2): 110-23. 